\title{
MEMETAKAN PESAN HOAKS BERITA COVID-19 DI INDONESIA LINTAS KATEGORI, SUMBER, DAN JENIS DISINFORMASI
}

\author{
Mapping Hoax Messages of COVID-19 in Indonesia Accros \\ Categories, Sources, and Types of Disinformation
}

\author{
1)*Oemar Madri Bafadhal, ${ }^{2}$ Anang Dwi Santoso \\ 1) 2)Universitas Sriwijaya \\ Jl. Raya Palembang - Prabumulih Km. 32 Indralaya, OI, Sumatera Selatan 30662
}

Diterima 29 Mei 2020 / Disetujui 27 Agustus 2020

\begin{abstract}
It is projected that the spread of disinformation infodemic among the COVID-19 pandemic will be as quickly or even more rapidly than the virus itself. The absence of the government in quickly and accurately providing information is suspected of being the basis of this phenomenon. Several studies have attempted to examine how the disinformation is shared, absorbed and driven to other behaviors. Meanwhile, no preliminary study maps the features of disinformation to be used practically for prevention and for overcoming disinformation itself. This study aims to fill this gap by examining 174 disinformation during the pandemic of COVID-19. There are five types of COVID-19 disinformation in Indonesia, namely governance, health, foreign relations, business and crime. We argue that if these five categories are not taken seriously, they will create a public distrust of government and science. Another result that arises is the apathy towards the virus which will endanger the wider community. On the basis of these results, we propose a strict government intervention in the provision of knowledge and clarification of disinformation in different forms of social media.
\end{abstract}

Keywords: hoax news, COVID-19, disinformation, misinformation

\begin{abstract}
ABSTRAK
Infodemi disinformasi di tengah pandemi COVID-19 diproyeksi sama cepat atau bahkan lebih cepat dari virus itu sendiri. Fenomena ini ditengarai terjadi karena absennya negara dalam menyediakan informasi yang cepat dan tepat. Berbagai macam studi telah mencoba menguji bagaimana disinformasi dibagikan, dikonsumsi dan mengarahkan masyarakat untuk melakukan aktivitas tertentu. Sementara itu belum ada studi pendahuluan yang memetakan karakteristik disinformasi secara praktis untuk dimanfaatkan bagi tindakan preventif dan penanggulangan disinformasi itu sendiri. Studi ini bertujuan untuk mengisi celah tersebut dengan menganalisis 174 disinformasi selama pandemi COVID-19. Hasil penelitian menunjukkan terdapat lima kategori disinformasi tentang COVID-19 di Indonesia yaitu politik, kesehatan, luar negeri, bisnis, dan kriminalitas. Kami berargumen bahwa kelima kategori tersebut jika tidak ditangani secara serius akan memunculkan sikap ketidakpercayaan publik terhadap otoritas pemerintah dan ilmu pengetahuan. Akibat lain yang muncul adalah sikap apatis terhadap virus tersebut yang akan membahayakan masyarakat luas. Berdasarkan temuan tersebut, kami merekomendasikan kehadiran pemerintah yang tegas dalam memberikan informasi serta mengklarifikasi disinformasi yang muncul di berbagai macam media sosial.
\end{abstract}

Kata Kunci: berita hoaks; COVID-19; diinformasi; misinformasi

*Korespondensi penulis:

Email:Oemarmadribafadhal @ fisip.unsri.ac.id 


\section{PENDAHULUAN}

"Combating misinformation and disinformation, especially during a pandemic, it's a civic duty that requires everyone's involvement" (Carvin, 2020).

Penyebaran COVID-19 sebagai suatu virus diiringi pula dengan berlimpahnya disinformasi tentang virus tersebut (Tasnim, Hossain, \& Mazumder, 2020). Sebagaimana COVID-19 telah mencapai hampir setiap negara di dunia, sirkulasi massal disinformasi melalui berita bohong dan fitnah menyebar secepat persebaran virus tersebut (Pulido Rodríguez et al., 2020). Retorika kebohongan di dalam disinformasi membuka jalan kacaunya masyarakat merespon pandemi ini dan berdampak pada terhambatnya upaya pemerintah merubah persepsi dan perilaku masyarakat. Infodemik yang melimpah juga digambarkan sebagai penyakit sekunder yang menyertai COVID-19 (Hua \& Shaw, 2020; Pennycook, McPhetres, Zhang, \& Rand, 2020).

Disinformasi didefinisikan sebagai distribusi atau diseminasi informasi bohong, palsu, keliru, atau menyimpang secara sengaja yang bertujuan untuk menyesatkan, menipu, atau membingungkan pihak penerima (Fetzer, 2004; Vlăduţescu \& Tenescu, 2014). Disinformasi tentang COVID-19 muncul dalam berbagai topik, mulai dari berbagai informasi yang salah mengenai etiologi, pencegahan dan penyembuhan virus, teori konspirasi tentang kesengajaan Cina membuat virus ini sebagai senjata biologis sampai dengan karakteristik virus ini yang hancur di air. Masalah muncul ketika disinformasi ini muncul, menyebar, viral dan dikonsumsi secara besar-besaran sehingga mengganggu keseimbangan keaslian ekosistem berita (Grace, 2020; Larson, 2020).

Dampak paling buruk dari pengkonsumsian berita disinformatif adalah beralihnya orang-orang ke pengobatan yang tidak efektif dan berpotensi membahayakan nyawa, timbulnya reaksi berlebihan masyarakat seperti pembelian secara panik produk tertentu, serta munculnya ketidakpercayaan kepada otoritas karena adanya informasi yang keliru tentang bagaimana mereka berkerja dalam pandemi ini (Cuan-Baltazar, Muñoz-Perez, Robledo-Vega,
Pérez-Zepeda, \& Soto-Vega, 2020; Hua \& Shaw, 2020). Ini kemudian menjadi masalah serius dalam kesehatan masyarakat karena paparan disinformasi dengan volume yang tinggi akan menyebabkan perlilaku yang salah sebagai akibat dari konsumsi berita tersebut. Selain itu, informasi yang salah mengenai COVID-19 juga berakibat pada tertutupinya informasi mengenai perilaku sehat karena ia mempromosikan praktik-praktik keliru yang meningkatkan penyebaran virus dan pada akhirnya menghasilkan perilaku kesehatan yang salah (Orso, Federici, Copetti, Vetrugno, \& Bove, 2020; Pulido Rodríguez et al., 2020).

Banyak informasi yang salah mengenai diagnosis dan pengobatan COVID19 telah membawa publik dan penyedia layanan kesehatan pada kebingungan. Ini juga diakibatkan karena masih kurangnya hasil penelitian dan diseminasi informasi mengenai COVID-19 (Shereen, Khan, Kazmi, Bashir, \& Siddique, 2020). Tipuan-tipuan ini juga, pada akhirnya, mengurangi kepatuhan terhadap karantina rumah dan isolasi fisik (Radecki \& Spiegel, 2020). Selain itu, absensi otoritas menghasilkan informasi yang kredibel membangkitkan publik untuk, secara mandiri, belajar lebih banyak tentang penyakit ini. Akibatnya adalah situasi ini membutuhkan jaminan yang dilengkapi dengan aliran informasi yang benar.

Disinformasi mengenai subyek kesehatan bukanlah merupakan fenomena baru, ia mungkin sama tuanya dengan ilmu kesehatan itu sendiri (Davis, 1984). Disinformasi bukan isu baru dalam dunia kesehatan. Praktisi dan akademisi telah bersepakat bahwa jenis berita ini menghadirkan risiko yang serius utamanya bagi kesehatan masyarakat dan perilaku pubik (de Regt, Montecchi, \& Lord Ferguson, 2019; Naskar, 2019; Wang, McKee, Torbica, \& Stuckler, 2019; Waszak, Kasprzycka-Waszak, \& Kubanek, 2018). Kesehatan masyarakat dihadapkan pada risiko terpaparnya pasien pada informasi yang menyesatkan. Ini, tentunya, akan mempengaruhi literasi kesehatan dan menyebarkan menyebarkan teori konspirasi medis. Dalam berbagai literatur, munculnya disinformasi diyakini didasari oleh dua motif utama yaitu finansial dan ideologis (Tandoc, Lim, \& Ling, 2018). Pada akhirnya, ini menjadi ancaman yang 
serius bagi kesehatan masyarakat karena mampu mempengaruhi perilaku masyarakat.

Pemahaman mengenai kategori dan sumber berita disinformatif tentang COVID-19 secara praktis akan bermanfaat dalam mengembangkan strategi untuk mengurangi penyebaran informasi yang salah di tengah pandemi ini. Tulisan ini, secara lebih spesifik, bertujuan untuk mengelompokkan disinformasi dalam jenis, kategori, dan klaim tertentu. Utamanya untuk melihat pola disinformasi seperti apa yang beredar di Indonesia. Selain itu, kami juga menganalisis sumber disinformasi (di media sosial mana saja berita disinformatif banyak ditemukan serta aktor yang mengklarifikasi berita tersebut (pemerintah, media masa dan lain sebagainya). Diharapkan penelitian ini dapat memberikan wawasan yang bermanfaat untuk penelitian tentang penyebaran informasi ketika krisis nantinya.

\section{Disinformasi}

Disinformasi merujuk pada distribusi atau diseminasi informasi bohong, palsu, keliru, atau menyimpang secara sengaja yang bertujuan untuk menyesatkan, menipu, atau membingungkan pihak penerima. Kebohongan kemudian menjadi elemen persuasif utama yang memanfaatkan ambiguitas dari bahasa kita untuk mendorong masyarakat melakukan suatu tindakan tertentu. Kesalahan informasi yang diberikan ke publik, pada akhirnya menentukan bagaimana cara mereka bertindak dan menyebarkan penilaian moral tertentu kepada masyarakat yang membaca disinformasi tersebut (Fetzer, 2004; Vlăduţescu \& Tenescu, 2014).

Dalam konteks tertentu disinformasi merupakan salah satu dari berbagai strategi politik (Balmas, 2014; Corner, 2017; Fensi, 2018; Molina, Sundar, Le, \& Lee, 2019). Disinformasi pada awalnya mengacu pada kampanye untuk menyebarkan propadganda politik dengan tujuan tertentu, mengacu pada kerangka kerja informasi yang terorganisir dan dengan hati-hati diarahkan untuk mencapai konsesnsus publik tentang suatu tujuan baik yang tersirat ataupun tersurat. Tujuan penyebaran berita semacam ini mengarah pada mobilisasi atau merawat imajinasi pemilih dengan retorika rasis, anti keragaman, anti hak asasi manusia (Ilahi, 2019; Utami, 2019). Hal ini terjadi karena disinformasi menyasar pada kerentanan yang timbul dari masalah kerberlangsungan hidup, misalnya ketakutan terhadap suatu hal yang tidak diketahui dan kecemasan yang dirasakan karena hilangnya sumber daya ekonomi, geografis, budaya dan lain sebagainya (Bafadhal, 2017), yang pada akhirnya membuat mereka mengambil realitarealita alternatif yang ditawarkan.

Secara tradisional, penyebaran berita disinformatif dilakukan dengan memalsukan dokumen dan menanam propaganda di koran. Sementara, saat ini berita disinformatif dilakukan dengan memodifikasi konten dengan menggunakan berbagai aplikasi untuk mengedit foto, generator kliping koran, simulator suara, atau perangkat lunak video untuk membuat konten visual yang difabrikasi tetapi dapat dipercaya, dan lain sebagainya (Utami, 2019). Fungsi penyebaran berita semacam ini adalah untuk menciptakakan imajinasi tentang adanya dunia alternatif dengan menetapkan kepalsuan sebagai fakta.

\section{Disinformasi di Kala Pandemi}

Pertanyaan mengapa individu, masyarakat dan institusi tertentu lebih rentan terhadap berita disinformatif saat ini sedang menarik untuk didiskusikan. Akademisi dan praktisis kesehatan masyarakat saat ini menaruh perhatian pada potensi internet sebagai medium untuk membagikan informasi kesehatan (Carmo-Fonseca, Mendes-Soares, \& Campos, 2002; Craan \& Oleske, 2002; Tan \& Goonawardene, 2017). Secara lebih spesifik, ponsel pintar, media sosial, dan teknologi seluler lainnya berkontribusi pada intervensi pencegahan penyakit tertentu dan peningkatan kesadaran kesehatan masyarakat (Ridout \& Campbell, 2018). Beberapa diantara keuntungannya adalah biaya yang murah dan jangkauan audiens yang lebih luas (Lee Ventola, 2014). Di sisi lain internet juga telah terbukti menjadi medium penyebaran informasi yang salah, termasuk berita palsu di dalamnya. Penyebaran berita disinformatif menghasilkan berbagi macam diskusi seperti perubahan perilaku sebagai akibatnya (Waszak et al., 2018).

Secara lebih spesifik, di era COVID19, beberapa studi telah diakukan, kaitanya dengan bagaimana berita hoaks, fake news, disinformasi dibagikan, dikonsumsi dan mengarahkan masyarakat untuk melakukan aktivitas tertentu (Grace, 2020; Larson, 2020; 
Pennycook et al., 2020; Tasnim et al., 2020). Disinformasi di kala pandemi kemudian menjadi penting untuk dikaji karena sebagaimana yang diungkap di awal, dapat membahayakan masyarakat luas. Berangkat dari riset-riset terdahulu tersebut, kami berargumen bahwa perlu dilaksanakan riset dasar untuk mengidentifikasi karakteristik disinformasi dimana dia dibagikan, apa saja tema yang muncul, dan siapa saja aktor yang mengklarifikasi kebenaran berita.

\section{METODE PENELITIAN}

Penelitian ini bertujuan untuk mengidentifikasi disinformasi dari sisi jenis, sumber dan klaim kesalahan informasi terkait COVID-19. Untuk mencapai tujuan tersebut kami memperkerjakan analisis konten sistematis terhadap disinformasi yang ada didalam situs Hoax Buster pada alamat https://covid19.go.id/p/hoax-buster. Hoax Buster adalah platfrom dari pemerintah yang menyediakan daftar disinformasi yang berisi pembahasan dari masing-masing artikel disinformatif secara rinci. Termasuk di dalamya adalah artikel disinformatif, klarifikasi, sumber berita, dan rujukan mengenai informasi yang sebenarnya. Meskipun secara terminologis, situs tersebut menggunakan istilah hoaks, kami menggunakan istilah disinformasi dalam menyebut berita atau informasi palsu yang ada di situs tersebut. Penyebutan kata disinformasi dirasa lebih konseptual karena informasiinformasi palsu yang disebar di kala pandemi secara teoritis memiliki tujuan tertentu baik secara ekonomi atau politis untuk menyesatkan, menipu, dan membingungkan

Tabel 1. Kategori dan Deskripsi Disinformasi

\begin{tabular}{|c|c|c|}
\hline Kategori & Sub Kategori & Deskripsi \\
\hline Bisnis & Bisnis & $\begin{array}{l}\text { Kategori ini memuat disinformasi yang menurunkan citra } \\
\text { perusahaan dengan membuat berita palsu tentang } \\
\text { tindakan-tindakan tertentu yang dilakukan oleh } \\
\text { perusahaan. }\end{array}$ \\
\hline Kriminalitas & Kriminalitas & $\begin{array}{l}\text { Kategori ini berisi berita bohong tentang kejadian } \\
\text { criminal di suatu tempat. }\end{array}$ \\
\hline \multirow[t]{3}{*}{ Luar Negeri } & Cina & $\begin{array}{l}\text { Ini menceritakan tentang bagaimana penanganan } \\
\text { COVID-19 di Cina }\end{array}$ \\
\hline & Italia & $\begin{array}{l}\text { Sebagaimana disinformasi tentang Cina, kategori ini } \\
\text { berisi tentang dinamika COVID-19 di Italia }\end{array}$ \\
\hline & Amerika Serikat & $\begin{array}{l}\text { Berisi disinformasi tentang COVID-19 di Amerka } \\
\text { Serikat. }\end{array}$ \\
\hline \multirow[t]{5}{*}{ Kesehatan } & Karakteristik COVID-19 & $\begin{array}{l}\text { Berita ini disajikan untuk membantu pembaca } \\
\text { menemukan karakteristik COVID-19, utamanya tentang } \\
\text { bagaimana transmisinya. }\end{array}$ \\
\hline & $\begin{array}{l}\text { Pengobatan/Pencegahan } \\
\text { COVID-19 } \\
\text { Penyebab COVID-19 }\end{array}$ & $\begin{array}{l}\text { Bagaimana COVID-19 dicegah dan diobati adalah } \\
\text { disinformasi yang termasuk dalam kategori ini. } \\
\text { Ini berisi tentang penyebab COVID-19. }\end{array}$ \\
\hline & Pasien COVID-19 & $\begin{array}{l}\text { Berita tentang bagaimana karakteristik pasien positif } \\
\text { Covis-19 tersaji dalam kategori ini. }\end{array}$ \\
\hline & Penemuan COVID-19 & $\begin{array}{l}\text { Penemuan COVID-19 di suatu lokasi tersaji dalam } \\
\text { kategori ini }\end{array}$ \\
\hline & $\begin{array}{l}\text { Tata cara penguburan } \\
\text { korban }\end{array}$ & $\begin{array}{l}\text { Ini menjawab tentang pertanyaan bagaimana pasien } \\
\text { COVID-19 seharusnya dikuburkan }\end{array}$ \\
\hline \multirow[t]{4}{*}{ Politik } & Jokowi & $\begin{array}{l}\text { Kategori Jokowi adalah berisi tentang berita bohong } \\
\text { tentang Joko Widodo }\end{array}$ \\
\hline & Kebijakan & $\begin{array}{l}\text { Kebijakan-kebijakan pemerintah yang salah atau tidak } \\
\text { sebenarnya benar-benar dibuat termasuk dalam kategori } \\
\text { ini. }\end{array}$ \\
\hline & Kebijakan lockdown & $\begin{array}{l}\text { Ini adalah kategori yang berisi tentang ditutupnya suatu } \\
\text { lokasi dan kebijakan lockdown di suatu } \\
\text { kabupate/kota/provinsi }\end{array}$ \\
\hline & Public figure & $\begin{array}{l}\text { Sebagaimana kategori Jokowi, kategori ini } \\
\text { menggambarkan bagaimana seroang tokoh publik } \\
\text { diserang malalui disinformasi. }\end{array}$ \\
\hline
\end{tabular}


pihak penerima. Untuk menangkap nuansa tersebut kami menggunakan konsep disinformasi bukan hoaks.

Peneliti mengumpulkan data disinformasi dari 16 Maret-22 April 2020. Proses pengambilan data dilakukan secara manual dari tanggal 23 April-30 April 2020. Sebuah dataset yang berisi 174 disinformasi terkumpul untuk analisis konten. Secara lebih detail, dari setiap dataset kami mendapatkan informasi mengenai tanggal, judul, isi disinformasi, sumber, klarifikasi, dan aktor yang mengklarifikasi disinformasi tersebut. Kami kemudian melakukan analisis konten utamanya untuk mengelompokkan setiap disinformasi ke dalam kategori tertentu. Selain itu, kami juga mengelompokkan sumber disinformasi serta aktor yang mengklarifikasi berita disinformasi.

Pengodean dan analisis konten dilakukan dengan mengimpor data ke dalam Microsoft Excel. Secara khusus kami memperkerjakan analisis konten interpretatif kualitatif (Krippendorff, 2013) untuk mengelompokkan disinformasi-disinformasi tersebut pada suatu kategori. Dikarenakan, sejauh pengamatan kami, belum ada penelitian yang mencoba mengelompokkan karakteristik disinformasi tentang COVID-19, kami memilih strategi untuk mebuat daftar kategori dan sub kategori baru. Kami secara hati-hati membaca setiap data (disinformasi) untuk dikelompokkan dalam kategori atau subkategori tertentu dan secara bertahap kategori tersebut dimodifikasi dan diperluas secara induktif.

Kami juga melakukan pengkodean dalam tiga tahapan sebagaimana direkomendasikan oleh Bellström et al (2016). Tahap pertama pengkodean dan analisis dilaukan oleh penulis pertama dan menghasilkan serangkaian kategori. Penulis kedua juga melakukan hal yang sama dan juga menghasilkan serangkaian kategori. Satu asisten peneliti yang tidak bergabung dalam penelitian ini kemudian memproses kedua daftar tersebut dan apabila terjadi perbedaan kode ketiga penulis mendiskusikan sampai bertemu pada suatu kesepakatan. Akhirnya, kami menyusun serangkaian kategori sebagaimana terdapat dalam Tabel 1 .

\section{HASIL DAN PEMBAHASAN}

$\mathrm{Bab}$ ini berisi tentang temuan penelitian yang dibagi kedalam lima bagian. Pertama kami akan menyajikan kategori dan sub kategori disinformasi tentang COVID-19. Sub-kategori ini secara tidak langsung juga dapat dibaca sebagai klaim pengetahuan yang ada di disinformasi tersebut. Selanjutnya adalah media sosial dimana disinformasi dibagikan dan diikuti dengan pihak yang mengklarifikasi pemberitaan disinformatif.

\section{Kategori Disinformasi}

Gambar 1 menunjukkan kategori disinformasi tentang Covid 19. Secara umum kami menemukan lima kategori dari 174 disinformasi yang kami dapatkan dari Hoax Buster. Kelima kategori tersebut antara lain: politik, kesehatan, luar negeri, bisnis, dan

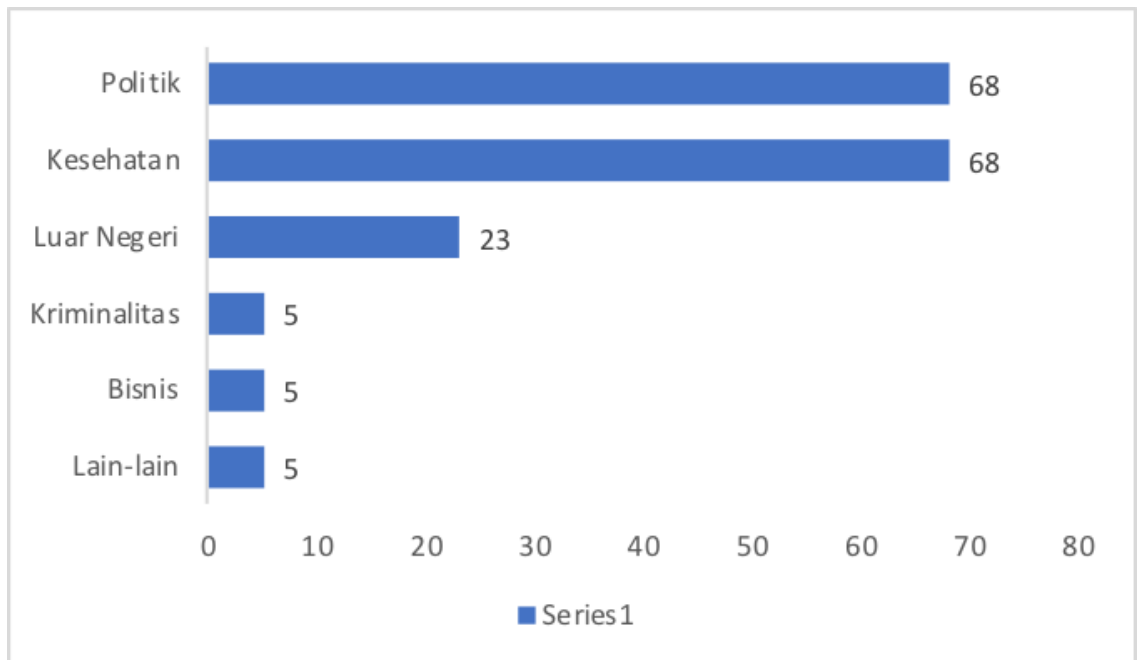

Gambar 1. Kategori disinformasi tentang COVID-19

Sumber: diolah peneliti, 15 Mei 2020 
kriminalitas. Diurutan pertama adalah ketrgori politik dan kesehatan dengan jumlah masingmasing 68 berita. Kategori kesehatan berisi berita-berita disinformatif mengenai karakteristik dan penyebab COVID-19 serta bagaimana cara mencegah dan menyembuhkannya. Termasuk didalamnya adalah pasien COVID-19, penemuan COVID19 dan tata cara penguburan korban COVID19. Sementara itu kategori politik, berisi tentang pemberitaan yang salah mengenai tokoh politik, kebijakan publik untuk urusan COVID-19, dan kebijakan lockdown.

Informasi yang tidak benar tentang kondisi COVID-19 di Cina, Amerika Serikat dan Italia ditemukan sebanyak 23 berita, kemudian kami kategorikan sebagai kategori luar negeri. Kategori berikutnya adalah bisnis. Kategori ini memuat berita-berita yang menjatuhkan citra suatu perusahaan atau bisnis yang kami temukan sebanyak 5 berita. Kemudian, berita palsu mengenai kriminalitas di suatu daerah yang diakibatkan oleh COVID19 kami temukan sebanyak 5 berita disinformatif. Semua berita yang tidak termasuk di dalam kategori-kategori tersebut kami labeli dengan lain-lain yang ditemukan sebanyak 5 berita.

Karena masih terlalu umum untuk dikaji, kami memutuskan untuk membagi setiap kategori ke dalam sub kategori yang lebih spesifik. Ini dimaksudkan untuk memberikan gambaran yang lebih spesifik mengenai disinformasi apa saja yang diproduksi. Dari lima kategori yang telah disampaikan sebelumnya kami pecah lagi menjadi 15 sub kategori sebagaimana terdapat dalam Tabel 2. Bagian selanjutnya mengulas tentang masing-masing sub kategori.

\section{Bisnis}

Kategori bisnis dan kriminalitas masing-masing memilki lima artikel disinformatif. Pada kategori bisnis, secara spesifik artikel mengabarkan informasi yang tidak benar mengenai perusahaan tertentu. Beberapa perusahaan yang menjadi sasaran antara lain Tempo dengan memberikan gambar sampul yang salah. Selain itu terdapat pula peberitaan yang salah mengenai penggeratisan layanan Netflix selama karantina. Berita lain adalah dijualnya beberapa hotel di bali karena sepi pengunjung dan mibil-mobil yang dijual karena kreditur mengalami gagal bayar.

\section{Kriminalitas}

Kategori kriminalitas berisi mengenai informasi palsu yang berusaha meresahkan masyarakat dengan memberikan berbagai informasi kejahatan akibat COVID-19. Diantara berita-berita yang termasuk kategori ini adalah pembunuhan masal berkedok COVID-19 dan pembunuhan pemuka agama.

Tabel 2. Kategori dan Sub kategori disinformasi

\begin{tabular}{lll}
\hline Kategori & Sub-Kategori & Jumlah \\
Bisnis & Bisnis & 5 \\
Kriminalitas & Kriminalitas & 5 \\
Luar Negeri & Cina & 6 \\
& Italia & 12 \\
& Amerika Serikat & 5 \\
Kesehatan & Karakteristik COVID-19 & 9 \\
& Obat/Pencegahan COVID-19 & 29 \\
& Penyebab COVID-19 & 5 \\
& Pasien COVID-19 & 8 \\
& Penemuan Virus COVID-19 & 12 \\
Politik & Tata cara penguburan korban & 5 \\
& Jokowi & 8 \\
& Aksi pemerintah & 19 \\
& Public figure & 17 \\
Lain-lain & Kebijakan Lockdown & 24 \\
\hline
\end{tabular}

Sumber: diolah peneliti, 15 Mei 2020 
Selain itu terdapat pula berita kejahatan seperti perampokan dan pembegalan hingga kedatangan polisi dari India untuk membantu mengamankan kondisi Indonesia selama pandemi.

\section{Luar Negeri}

Dibanding negara-negara lain, pemberitaan palsu mengenai kondisi dan situasi COVID-19 yang terjadi di Cina, Amerika Serikat dan Italia mendominasi data disinformasi yang kami kumpulkan. Cina dalam berita-berita disinformasi yang dibagikan digambarkan sebagai negara yang dengan sengaja menciptakan COVID-19 dengan tujuan tertentu seperti membunuh masyarakat Indonesia dan ulama. Informasi palsu tentang Cina juga masih seputar tenaga kerja asing (TKA) dan komunis. Kami menemukan enam disinformasi dalam kategori ini. Sementara itu berita disinformasi tentang Amerika Serikat ditemukan sebanyak 5 berita. Secara umum, negara ini digambarkan sebagai negara yang gagal menangani COVID-19 karena beberapa hal seperti terjadi penjarahan, harus meminta bantuan negara lain dan jumlah pasien COVID-19 yang banyak.

Terakhir adalah Italia. Sama seperti Amerika Serikat, negara ini diilustrasikan sebagai negara yang gagal menangani COVID-19. Berita-berita disinformatif tentang Italia menunjukkan kefrustasian negara tersebut dalam mengelola COVID-19. Ini digambarkan melalui beberapa potongan gambar yang pada akhirnya membentuk gambaran Italia sebagai negara yang gagal menangani persoalan ini. Potongan-potongan gambar tersebut antara lain, kekurangan lahan untuk mengubur korban, rumah sakit yang tidak lagi bisa menampung pasien, menurunnya nilai tukar mata uang Italia, sampai dengan pengumuman shut down. Beberapa berita juga menggambarkan bersujudnya masyarakat Italia dan bergemanya takbir di Italia. Dibandingkan dengan Cina dan Amerika Serikat, berita disinformasi tentang Italia adalah paling banyak, ditemukan sebanyak 12 .

\section{Kesehatan}

Berita disinformatif tentang kesehatan juga mendominasi dataset kami. Kami menemukan 43 berita yang kemudian dibagi ke dalam tiga sub kategori. Pertama adalah karakteristik COVID-19. Secara umum, disinformasi dalam kategori ini berusaha mengkonstruksi pembaca bagaimana karakteristik COVID-19. Secara spesifik, disinformasi menggambarkan COVID-19 sebagai virus yang memiliki karakteristik seperti hacur dengan air dan berupa jamur atau mould. Dalam kategori ini kami juga mengidentifikasi disinformasi yang berusaha menganalisis penyebab corona. Diantaranya adalah salah kepemimpinan dan tindakan mendzalimi perempuan muslim Uighur.

Selanjutnya adalah sub kategori obat atau pencegahan COVID-19. Ini berisi tentang berbagai macam tindakan atau zat-zat tertentu yang dapat menyembuhkan atau mencegah virus ini. Beberapa diantaranya menyebutkan bahwa COVID-19 bisa dicegah atau disembuhkan dengan alkohol, mengkonsumsi pisang, meminum air, ganja, bawang merah, Dettol, memasukkan Amoxilin dalam tandon air, berendam di air laut, memium vitamin $\mathrm{C}$, memakan makanan yang mengandung alkali, mengkonsumsi lemon, sampai dengan merokok. Beberapa tindakan-tindakan agama seperti mendengarkan suara adzan, pergi ke masjid, sholat jumat, sholat taubat, dan membaca asmaul husna juga digambarkan sebagai aktivitas-aktivitas yang dapat melawan COVID-19. Beberapa berita disinformatif juga menginformasikan adanya penemuan vaksin di Cina dan Amerika Serikat.

Berita disinformatif tentang Pasien COVID-19 adalah berita yang berusaha menggambarkan pasien COVID-19 sebagai pasien yang susah diatur. Mereka mencoba melawan dengan melarikan diri dari rumah sakit. Beberapa berita juga menggambarkan karakteristik pasien COVID-19. Berita semacam ini ditemukan sebanyak 8 berita. Selanjutnya adalah berita tentang penemuan COVID-19 di atat transportasi seperti kapal dengan rute Banda Aceh-Sabang, pesawat, dan pelabuhan benda tertentu seperti tisu toilet, di beberapa wilayah seperti Pare-pare, di Purwakarta, di Atambua. Berita ini ditemukan sejumlah 12 berita.Sebanyak 5 berita ditemukan termasuk dalam sub kategori tata cara penguburan jenazah. Berita-berita yang termasuk dalam kategori ini, secara spesifik, menceritakan bagaimana seharusnya jenazah dikubur dan langkah-langkah tertentu yang harus diambil sebelum menguburkan jenazah pasien COVID-19. 


\section{Politik}

Kategori selanjutnya yang akan diulas adalah politik. Secara umum, kami membagi kategori ini menjadi empat sub kategori yaitu mengenai Presiden Jokowi, aksi pemerintah dalam penanganan COVID-19, figur publik, dan kebijakan lockdown yang masing-masing ditemukan sebanyak 8, 19, 17, dan 24 secara berurutan. Berita menyimpang tentang Jokowi didominasi berita-berita bernada negatif tentang Jokowi, termasuk di dalamnya adalah Jokowi positif COVID-19, Jokowi salah membeli obat dari Cina, dan Jokowi korupsi.

Beberapa berita disinformasi juga berisi tentang aksi pemerintah dalam penanganan COVID-19. Termasuk diantaranya adalah kompensasi bagi driver grab, penutupan seluruh BUMN di DKI surat edaran Walikota Palembang, peliburan seluruh universitas di Jakarta, penuapan lokasi karantina, penggeratisan internet, dan pembuatan kartu corona sehat. Sementara itu, berita tentang figur publik berisi berita positif ataupun berita negatif yang salah tentang tokoh poltiik tertentu. Beberapa tokoh politik yang namanya disebut dalam disinformasi antara lain Nadiem Makarim, Prabowo, dan Anies Baswedan.

Sub kategori kebijakan lockdown berisi tentang ditemukannya COVID-19 di suatu wilayah atau tempat tertentu sehingga mengharuskan tempat tersebut ditutup sementara atau bahkan lockdown. Tempat- tempat tertentu yang termasuk di dalamnya adalah pusat bisnis seperti pasar dan mall, pelabuhan dan transportasi publik. beberapa kota/kabupaten juga diisukan memutuskan atau diputuskan lockdown seperti Bali, Jakarta, Purwokerto, Makassar, Cirebon,dan Situbondo.

\section{Media Disinformasi}

Selain melakukan kategorisasi, kami juga melakukan analisis terhadap platform tempat disinformasi banyak ditemukan. Secara umum kami menemukan bahwa disinformasi dibagikan umumnya di macam media sosial seperti Facebook, Instagram, Twitter, WhatsApp dan YouTube meskipun ada beberapa yang muncul di situs atau Blog tertentu. Beberapa juga ditemukan dan dibagikan di dua media sosial seperti Twitter dan Facebook, Facebook dan YouTube, Facebook dan WhatsApp serta Facebook dan Website/blog. Peneliti menemukan bahwa media sosial tempat ditemukan banyak disinformasi mengenai COVID-19 adalah Facebook dan WhatsApp, masing-masing sebanyak 90 dan 43 artikel disinformatif. Mengikuti dibelakangnya adalah Twitter (17 disinformasi), Instagram (2 disinformasi), Website atau Blog (8 disinformasi) dan YouTube (1 disinformasi).

Facebook masih menjadi platform dominan untuk aktivitas penyebaran disinformasi. Dalam kurun beberapa bulan terakhir, Facebook sudah berulang kali

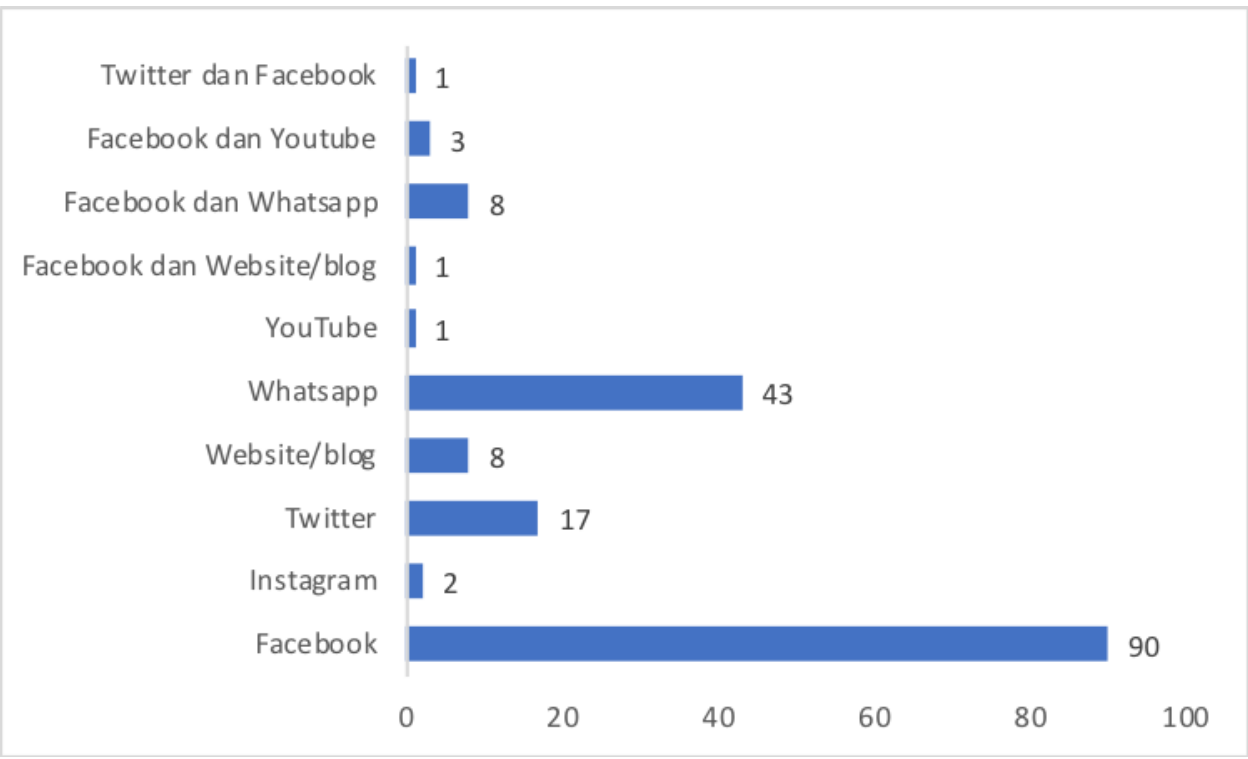

Gambar 2. Media Sosial dimana disinformasi ditemukan

Sumber: diolah peneliti, 15 Mei 2020 
melakukan berbagai inovasi untuk meredakan sirkulasi disinformasi di situs mereka (BBC, 2020). Mengingat jumlahnya masih cukup banyak. Artinya perlu ada evaluasi dari perusahaan media terkait usaha mereka untuk melandaikan kurva disinformasi. Selain kendala bahasa yang tidak terdeteksi oleh algoritma Facebook, disinformasi juga melakukan evolusi agar tidak bisa terdeteksi secara khusus, sehingga butuh pengembangan algoritma baru dalam menghadapi disinformasi.

WhatsApp juga mulai melimitasi jumlah pesan yang bisa diteruskan secara massal. Namun melihat data di atas, usaha tersebut belum bisa menahan laju penyebaran disinfomasi. Penyebaran disinformasi ini tentu menuntut perhatian semua kalangan, karena sebagaimana kita ketahui, usaha-usaha yang dilakukan oleh Facebook dan WhatsApp, belum bisa meredam penyebaran disinformasi.

Facebook dan WhatsApp menjadi media yang dominan dalam penyebaran disinformasi karena memiliki pengguna yang sangat besar. Selain itu Facebook sebagai sebuah medium juga ditujukan untuk komunikasi antara sahabat dekat dan keluarga, sekaligus juga sumber berita politis. Irisan antar keduanya menjadikan Facebook dan WhatsApp menjadi medium dominan untuk menyebarkan disinformasi. Dalam perspektif McLuhan, kebiasaan mengonsumsi medium ini pada akhirnya membentuk relasi khusus antar pengguna dan medium tersebut. Dalam kasus ini, irisan antara kedekatan pribadi dan konsumsi berita membuat medium tersebut berubah menjadi portal berita alternatif yang membentuk pikiran pengguna dan memberikan penggunanya berita yang tidak mungkin mereka dapatkan di kanal media mainstream (Bafadhal, 2017).

\section{Pihak yang Mengklarifikasi Disinformasi}

Pihak yang mengklarifikasi disinformasi juga dapat diidentifikasi dari portal Hoax Buster, sehingga kami dapat mengkategorisasikan siapa saja aktor-aktor yang terlibat. Secara umum terdapat tiga pihak yang berusaha mengklarifikas disinformasi yaitu media daring, komunitas, pemerintah, dan organisasi terkait. Kami menemukan bahwa kebanyakan disinformasi dikonfirmasi kekeliruannya oleh media daring. Media daring saat ini memiliki portal khusus untuk mengklarifikasi disinformasi melalui fitur cek fakta seperti di Tempo, Liputan6, dan Merdeka. Beberapa berita joaks juga diklarifikasi oleh komunitas atau dalam hal ini adalah Forum Anti Fitnah, Hasut dan Hoax. Pemerintah, meskipun porsinya tidak banyak, juga berusaha mengkonfirmasi disinformasi. Beberapa berita disinformatif juga ditemukan dikonformasi oleh dua aktor sekaligus yaitu media daring dan organisasi terkait (organisai yang diserang disinformasi) dan media daring dan pemerintah.

Dalam melakukan sanggahan terhadap pesan disinformasi, tidak cukup hanya dengan menunjukkan fakta-fakta yang salah. Namun sanggahan tersebut harus memiliki informasi

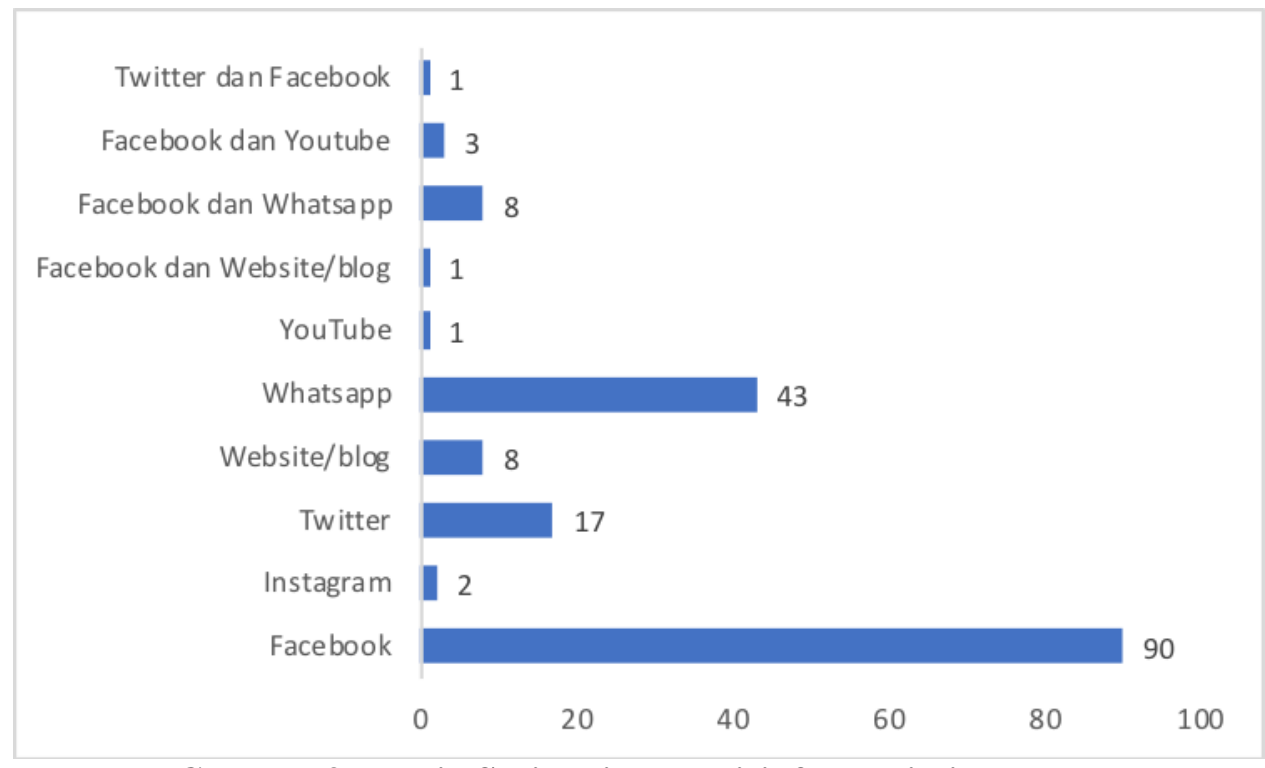

Gambar 3. Media Sosial dimana disinformasi ditemukan

Sumber: diolah peneliti, 15 Mei 2020 
baru yang rinci sehingga dapat membantu khalayak membangun narasi baru. Oleh karena itu, kami melakukan analisis lebih mendalam terhadap klaim-klaim yang diberikan oleh otoritas yang melakukan sanggahan terhadap disinformasi. Analisis mengacu pada rekomendasi dari Chan, Jones, Hall Jamieson, \& Albarracín (2017), sebagai berikut: berita tentang misinformasi tidak boleh mengulangulang atau merincikan pemikiran yang mendukung disinformasi, mengundang khalayak untuk berpikir tentang argument kontra, dan memberikan informasi baru.

Kami menemukan bahwa pemerintah sebagai otoritas masih cukup lemah karena berulang kali melakukan pengulangan terhadap disinformasi yang sudah beredar. Ketika pesan sanggahan sifatnya lemah, maka hal ini dapat berdampak pada melekatnya pesan utama dari disinformasi tersebut karena mengaktifkan bias di dalam benak pembacanya. Apabila pemerintah sebagai otoritas yang seharusnya bisa diandalkan dalam melakukan sanggahan tidak bisa melakukannya dengan baik, hal ini tentu dapat memicu ketidakpercayaan publik terhadap disinformasi. bisa jadi masih menjadi mata rantai yang lemah dalam proses klarifikasi disinformasi. Namun, jika pemerintah bisa melakukan sanggahan yang baik, maka akan muncul nilai-nilai skeptisisme masyarakat terhadap pesan-pesan yang ditengarai berisi disinformasi (Chan et al., 2017).

\section{Jenis Berita Disinformasi}

Sebagaimana ditampilkan dalam Gambar 4, kami menemukan empat jenis disinformasi yaitu misleading content, manipulated content, false content dan fabricated content. Secara umum, berita disinformasi dengan jenis misleading content banyak kami temukan. Ini berisi beberapa informasi yang benar namun detailnya dirumuskan ulang dengan cara tertentu. Beberapa berita dalam kategori ini menggabungkan informasi yang akurat dan tidak akurat tentang berbagai hal. Jenis lain adalah fabricated content atau berita yang benar-benar salah. Ini ditemukan sejumlah 74 berita. Mengikuti dibelakangnya adalah manipulated content dan false context dengan jumlah 19 dan 17 secara berurutan. Manipulated content berisi berita-berita yang diubah kontennya untuk mengecoh pembaca sementara itu false context berisi berita benar dengan narasi yang salah.

Tulisan ini bertujuan untuk memahami karakteristik disinformasi tentang COVID-19 di Indonesia. Secara umum, sebagian besar berita disinformasi mengandung fabrikasi langsung dengan mengedit gambar, memanipulasi konten berita, dan memberikan narasi yang salah terhadap suatu gambar ataupun berita sebagaimana ditemukan pada disinformasi lainnya (Ilahi, 2019; Utami, 2019). Secara spesifik kami menyajikan kategori, sumber, jenis dan siapa aktor yang mengklarifikasi disinformasi serta jenis disinformasi itu sendiri. Bagian ini berisi diskusi untuk menjawab mengapa disinformasi semacam itu dapat muncul dan bagaimana dampaknya bagi arus informasi mengenai Covid di Indonesia.

Dari karakteristik yang tergambar,

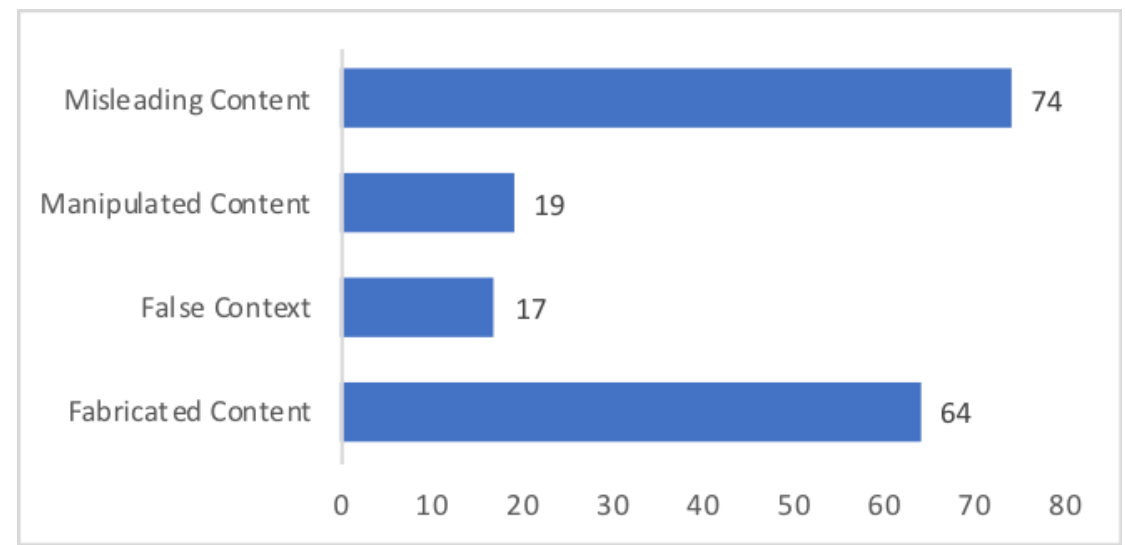

Gambar 4. Jenis Berita Disinformasi

Sumber: diolah peneliti, 15 Mei 2020 
kami menemukan bahwa disinformasi yang beredar di era pandemi COVID-19 ini digunakan untuk menimbulkan ketidakpercayaan pada otoritas-otoritas yang berurusan langsung dengan COVID-19 seperti pemerintah dan ilmu pengetahuan. Sebagaimana diungkapkan oleh (Brennen, Simon, Howard, \& Nielsen, 2020), disinformasi tentang tindakan pemerintah dan penyebaran virus secara umum selalu berlawanan dengan apa yang dianjurkan oleh otoritas, mulai dari negara dengan kebijakannya sampai dengan ilmu pengetahuan dengan berbagai riset yang dilakukannya.

Banyaknya disinformasi mengenai tindakan yang diambil oleh otoritas mengindikasikan bahwa pemerintah tidak selalu berhasil memberikan informasi yang jelas, berguna dan terpecaya untuk menjawab keingintahuan publik yang mendesak. Dengan absennya informasi yang memadai, berita disinformasi mengisi kekosongan ruang tersebut dalam pemahaman publik yang pada akhirnya membuat publik enggan mempercayai komunikasi resmi dari pemerintah (Djalante et al., 2020; Gao \& Yu, 2020)

Selain pemerintah, disinformasi juga menyasar di bidang kesehatan dan ilmu pengetahuan secara umum. Beberapa peneliti meyakini bahwa disinformasi terkait COVID19 memang ditujukkan agar masyarakat secara keliru berperilaku misalnya dengan mengkonsumsi obat-obatan herbal dan lain sebagainya (Larson, 2020; Pulido Rodríguez et al., 2020; Radecki \& Spiegel, 2020).

Wacana publik yang dipenuhi dengan disinformasi, sanggahan, serta merujuk pada komunikasi pemerintah yang ambigu akan menimbulkan kebingungan bahkan dapat menyebabkan sikap apatis serta membuat publik waspada terhadap pemerintah dan urusan publiknya (Fensi, 2019; LandonMurray, Mujkic, \& Nussbaum, 2019). Hal ini bisa dimanfaatkan oleh politisi untuk mencari celah elektabilitas, menegaskan posisinya di politik, dan mengambil kebijakan yang tidak diikuti dengan masukan dari publik.

Penyebaran berita disinformasi dan kaitannya daengan politik bukan suatu fenomena baru. Berita apapun bisa saja dimanipulasi untuk meningkatkan atau menurunkan citra dari seorang tokoh politik.
Studi jurnalisme pada abad kesembilan belas menemukan surat kabar yang umumnya bereksperimen dengan berita dan penulisan fiksi demi keuntungan (Roggenkamp, 2005). Sejalan dengan temuan tersebut, penelitian ini menemukan bahwa disinformasi tentang COVID-19 di Indonesia adalah pendalaman komunikasi politik abad kesembilan belas (Blumler, 2016), yang ditandai dengan kembalinya pesan partisan dan politik identitas (Blumler \& Kavanagh 1999). Hal ini didukung dengan narasi disinformasi yang banyak mengambil nilai ideal dari suatu komunitas sehingga tidak secara nyata menggambarkan suatu informasi, namun merupakan gambaran tentang bagaimana kuasa pemaknaan harus sejalan dengan pandangan disinformasi tersebut (Bafadhal, 2017).

Penelitian ini membuktikan bahwa pesan di media sosial digunakan sebagai sumber berita yang kemudian didefinisikan ulang. Selain itu, disinformasi ini dibagikan dan dibahas melalui jaringan online dalam hitungan menit atau bahkan detik. Komunitas online yang berbagi dan membahas disinformasi biasanya sekelompok individu yang memiliki pendapat dan sudut pandang yang sama (Brummette, DiStaso, Vafeiadis, \& Messner, 2018). Pada akhirnya berita disinformasi dipromosikan di berbagai macam platform media sosial untuk menipu publik demi keuntungan ideologis tertentu.

\section{SIMPULAN}

Penelitian ini bertujuan untuk menggambarkan karakteristik disinformasi di era pandemi COVID-19. Kami menemukan lima tema yang muncul yaitu politik, kesehatan, luar negeri, bisnis, dan kriminalitas. Dilihat dari sumbernya, studi ini menemukan bahwa Facebook and WhatsApp adalah dua media sosial yang paling sering digunakan untuk mebagikan disinformasi. Sementara itu, absennya pemerintah dalam mengklarifikasi disinformasi adalah kesempatan baru bagi media daring untuk hadir membantu pemerintah menyanggah berita disinformasi.

Ketidakhadiran pemerintah dalam menyediakan informasi cepat dan tepat kemudian menjadi kesempatan untuk menyebarkan berita bohong. Ini, secara lebih 
luas, dapat dimaknai sebagai upaya untuk menjatuhkan otoritas yang berkaitan langsung dengan penanganan COVID-19 mulai dari pemerintah sampai dengan tenaga medis. Pada akhirnya disinformasi ini dimanfaatkan oleh politisi sesuai dengan agendanya masingmasing.

Sementara bagi masyarakat dampak dari penyebaran disinformasi ini adalah sesaknya wacana publik dengan informasiinformasi yang membingungkan. Diseminasi pengetahuan saintifik yang berguna bagi masyarakat menjadi terhambat. Masyarakat dijejali dengan informasi mengenai berbagai pengobatan alternatif yang belum teruji, realita-realita di luar negeri yang palsu, dan anatomi virus yang tidak terbukti. Disinformasi ini juga pada akhirnya mendorong perilaku apatis pada masyarakat karena menciptakan kebingungan dan ketidakpercayaan terhadap otoritas pemerintah dan ilmu pengetahuan.

Secara akademis, studi ini berkontribusi sebagai studi dasar yang memetakan disinformasi tentang COVID-19. Secara praktis, kami merekomendasikan kehadiran pemerintah yang tegas dalam mengontrol disinformasi yang muncul di berbagai macam media sosial. Pemerintah perlu mengembangkan sistem inti mendeteksi disinformasi dan juga ikut meng-counter disinformasi dengan informasi yang valid. Selain itu, upaya preventif juga dapat dilakukan dengan membangun sebuah platform tentang karakteristik COVID-19 itu sendiri agar masyarakat tahu di mana mereka harus mencari berita tentang virus ini.

Studi ini memiliki beberapa kelemahan. Sebagai studi pendahuluan kami hanya menganalisis 174 disinformasi yang berasal dari situs hoax buster milik pemerintah. Studi selanjutnya, seiring dengan berkembangnya, berbagai komunitas daring fact checking dapat mengkombinasikan datadata dari berbagai macam komunitas tersebut untuk memeproleh hasil yang lebih komprehensif. Sebagai studi pendahuluan, kami tidak melihat popularitas dan viralitas meskipun satu berita disinformasi mungkin lebih popular dan viral dari berita lain. Studi selanjutnya dapat melakukan hal tersebut. Terakhir, studi selanjutnya juga dapat menilai dampak disinformasi terhadap perubahan perilaku masyarakat terutama untuk menjawab apakah berita disinformasi tersebut mendorong masyarakat untuk memiliki imajinasi sendiri mengenai virus ini dan lain sebagainya.

\section{DAFTAR PUSTAKA}

Bafadhal, O. M. (2017). Komunikasi Ritual Penggunaan Aplikasi WhatsApp: Studi Konsumsi Berita Lewat Group WhatsApp. Jurnal Komunikasi Indonesia, 6(1), 49-56. http://doi.org/10.7454/jki.v6i1.8628

Balmas, M. (2014). When Fake News Becomes Real: Combined Exposure to Multiple News Sources and Political Attitudes of Inefficacy, Alienation, and Cynicism. Communication Research, 41(3), 430-454. http://doi.org/10.1177/009365021245360 0

BBC. (2020, April 16). Coronavirus: Facebook alters virus action after damning misinformation report - BBC News. Retrieved May 20, 2020, from https://www.bbc.com/news/technology52309094

Bellström, P., Magnusson, M., Pettersson, \& Sören, J. (2016). Facebook usage in a local government: A content analysis of page owner posts and user posts. Transforming Government: People, Process and Policy, 10(4), 548-567. http://doi.org/doi:10.1108/TG-08-20130026

Blumler, J. G. (2016). The Fourth Age of Political Communication. Politiques de Communication, $\quad$ 1(19), 30. http://doi.org/https://doi.org/10.3929/ethz -b-000238666

BLUMLER, J. G., \& KAVANAGH, D. (1999). The Third Age of Political Communication: Influences and Features. Political Communication, 16(3), 209230.

http://doi.org/10.1080/105846099198596

Brennen, A. J. S., Simon, F. M., Howard, P. N., \& Nielsen, R. K. (2020). Types , Sources , and Claims of COVID-19 Misinformation. Oxford University Press, (April), 1-13.

Brummette, J., DiStaso, M., Vafeiadis, M., \& Messner, M. (2018). Read All About It: 
The Politicization of "Fake News" on Twitter. Journalism and Mass Communication Quarterly, 95(2), 497517. http://doi.org/10.1177/107769901876990 6

Carmo-Fonseca, M., Mendes-Soares, L., \& Campos, I. (2002). Patients' use of the Internet for medical information. Journal of General Internal Medicine, 17(3), 180-185. http://doi.org/10.1046/j.15251497.2002.10603.x

Carvin, A. (2020). Webinar 20: Covering an Infodemic: Disinformation Surrounding COVID-19. International Center for Journalists (ICFJ). Retrieved from https://www.youtube.com/watch?v=pTH HkmcsAkM

Chan, M. S., Jones, C. R., Hall Jamieson, K., \& Albarracín, D. (2017). Debunking: A Meta-Analysis of the Psychological Efficacy of Messages Countering Misinformation. Psychological Science, 28(11), 1531-1546. http://doi.org/10.1177/095679761771457 9

Corner, J. (2017). Fake news, post-truth and media-political change. Media, Culture \& Society, 39(7), 1100-1107. http://doi.org/10.1177/016344371772674 3

Craan, F., \& Oleske, D. M. (2002, December). Medical information and the internet: Do you know what you are getting? Journal of Medical Systems. Springer. http://doi.org/10.1023/A:1020240625200

Cuan-Baltazar, J. Y., Muñoz-Perez, M. J., Robledo-Vega, C., Pérez-Zepeda, M. F., \& Soto-Vega, E. (2020). Misinformation of COVID-19 on the Internet: Infodemiology Study. JMIR Public Health and Surveillance, 6(2), e18444. http://doi.org/10.2196/18444

Davis, D. L. (1984). Medical misinformation: Communication between outport Newfoundland women and their physicians. Social Science and Medicine, 18(3), 273-278. http://doi.org/10.1016/02779536(84)90090-X

de Regt, A., Montecchi, M., \& Lord Ferguson, S. (2019). A false image of health: how fake news and pseudo-facts spread in the health and beauty industry. Journal of
Product and Brand Management, 29(2), 168-179. http://doi.org/10.1108/JPBM12-2018-2180

Djalante, R., Lassa, J., Setiamarga, D., Sudjatma, A., Indrawan, M., Haryanto, B., ... Warsilah, H. (2020). Review and analysis of current responses to COVID19 in Indonesia: Period of January to March 2020. Progress in Disaster Science, $\quad 6, \quad 100091$. http://doi.org/10.1016/j.pdisas.2020.1000 91

Fensi, F. (2018). FENOMENA HOAX: Tantangan terhadap Idealisme Media \& Etika Bermedia. Bricolage: Jurnal Magister Ilmu Komunikasi, 4(02), 133. http://doi.org/10.30813/bricolage.v4i02.1 657

Fensi, F. (2019). Paradoxic Language "Cebong-Kampret" in Facebook As a Mirror of the Political Language of Indonesia. Bricolage: Jurnal Magister Ilmu Komunikasi, 5(02), 103. http://doi.org/10.30813/bricolage.v5i02.1 887

Fetzer, J. H. (2004). Disinformation: The Use of False Information. Minds and Machines, 14(2), 231-240. http://doi.org/10.1023/B:MIND.0000021 $683.28604 .5 b$

Gao, X., \& Yu, J. (2020). Public governance mechanism in the prevention and control of the COVID-19: information, decisionmaking and execution. Journal of Chinese Governance, 1-20. http://doi.org/10.1080/23812346.2020.17 44922

Grace, R. (2020, March 20). COVID-19 prompts the spread of disinformation across MENA | Middle East Institute. Retrieved May 17, 2020, from https://www.mei.edu/publications/COVI D-19-prompts-spread-disinformationacross-mena

Hua, J., \& Shaw, R. (2020). Corona virus (COVID-19) "infodemic" and emerging issues through a data lens: The case of china. International Journal of Environmental Research and Public Health, 17(7). http://doi.org/10.3390/IJERPH17072309

Ilahi, H. N. (2019). Women and Hoax News Processing on WhatsApp. Jurnal Ilmu Sosial Dan Ilmu Politik, 22(2), 98-111. 
http://doi.org/10.22146/JSP.31865

Krippendorff, K. (2013). Content analysis : an introduction to its methodology. SAGE. Retrieved from https://books.google.co.id/books/about/C ontent_Analysis.html?id=s_yqFXnGgjQ C\&redir_esc $=y$

Landon-Murray, M., Mujkic, E., \& Nussbaum, B. (2019). Disinformation in Contemporary U.S. Foreign Policy: Impacts and Ethics in an Era of Fake News, Social Media, and Artificial Intelligence. Public Integrity, 21(5), 512522.

http://doi.org/10.1080/10999922.2019.16 13832

Larson, H. J. (2020). Blocking information on COVID-19 can fuel the spread of misinformation. Nature, 580(7803), 306306. http://doi.org/10.1038/d41586-02000920-w

Lee Ventola, C. (2014). Social media and health care professionals: Benefits, risks, and best practices. $P$ and T, 39(7), 491.

Molina, M. D., Sundar, S. S., Le, T., \& Lee, D. (2019). "Fake News" Is Not Simply False Information: A Concept Explication and Taxonomy of Online Content. American Behavioral Scientist, 000276421987822.

http://doi.org/10.1177/000276421987822 4

Naskar, S. (2019). Viral or Virus?: A Content Analysis of Fake News Themes in the World's Largest Democracy from Jan 2017-May 2019. University of Nevada.

Orso, D., Federici, N., Copetti, R., Vetrugno, L., \& Bove, T. (2020). Infodemic and the spread of fake news in the COVID-19era. European Journal of Emergency Medicine, http://doi.org/10.1097/mej.00000000000 00713

Pennycook, G., McPhetres, J., Zhang, Y., \& Rand, D. (2020). Fighting COVID-19 misinformation on social media: Experimental evidence for a scalable accuracy nudge intervention. PsyArXiv [Working Paper], 1-24. http://doi.org/10.31234/OSF.IO/UHBK9

Pulido Rodríguez, C., Villarejo Carballido, B., Redondo-Sama, G., Guo, M., Ramis, M., \& Flecha, R. (2020). False news around COVID-19 circulated less on Sina Weibo than on Twitter. How to overcome false information? International and Multidisciplinary Journal of Social Sciences, $9(2), \quad 1$. http://doi.org/10.17583/rimcis.2020.5386

Radecki, R. P., \& Spiegel, R. S. (2020). Avoiding Disinformation Traps in COVID-19. Annals of Emergency Medicine.

http://doi.org/10.1016/j.annemergmed.20 20.05.002

Ridout, B., \& Campbell, A. (2018). The use of social networking sites in mental health interventions for young people: Systematic review. Journal of Medical Internet Research, 20(12), 1-11. http://doi.org/10.2196/12244

Roggenkamp, K. H. (2005). Narrating the News: New Journalism and Literary Genre in Late Nineteenth ... - Karen Hartmann Roggenkamp - Google Books. $\mathrm{OH}$ : Kent State University Press.

Shereen, M. A., Khan, S., Kazmi, A., Bashir, N., \& Siddique, R. (2020, July 1). COVID-19 infection: Origin, transmission, and characteristics of human coronaviruses. Journal of Advanced Research. Elsevier B.V. http://doi.org/10.1016/j.jare.2020.03.005

Tan, S. S. L., \& Goonawardene, N. (2017, January 1). Internet health information seeking and the patient-physician relationship: A systematic review. Journal of Medical Internet Research. Journal of Medical Internet Research. http://doi.org/10.2196/jmir.5729

Tandoc, E. C., Lim, Z. W., \& Ling, R. (2018, February 7). Defining "Fake News": A typology of scholarly definitions. Digital Journalism. Routledge. http://doi.org/10.1080/21670811.2017.13 60143

Tasnim, S., Hossain, M. M., \& Mazumder, H. (2020). Impact of rumors or misinformation on coronavirus disease (COVID-19) in social media. Journal of Preventive Medicine and Public Health. http://doi.org/10.3961/jpmph.20.094

Utami, P. (2019). Hoax in Modern Politics. Jurnal Ilmu Sosial Dan Ilmu Politik, 22(2), 85. http://doi.org/10.22146/jsp.34614

Vlăduţescu, Ş., \& Tenescu, A. (2014). Current Communication Difficulties. 
Wang, Y., McKee, M., Torbica, A., \& Stuckler, D. (2019). Systematic Literature Review on the Spread of Health-related Misinformation on Social Media. Social Science and Medicine, 240(September), 112552. http://doi.org/10.1016/j.socscimed.2019. 112552

Waszak, P. M., Kasprzycka-Waszak, W., \& Kubanek, A. (2018). The spread of medical fake news in social media - The pilot quantitative study. Health Policy and Technology, 7(2), 115-118. http://doi.org/10.1016/j.hlpt.2018.03.002 